UDC 621.86:622.678

V.S. Loveikin, Dr. Sc. (Tech.), Prof., orcid.org/0000-0003-4259-3900,

Yu. O. Romasevych, Dr. Sc. (Tech.), Assoc. Prof., orcid.org/0000-0001-5069-5929

\title{
REGIME-PARAMETRIC OPTIMIZATION OF A MINE WINDER DECELERATION
}

Purpose. Improving mine winder operation efficiency during deceleration of the final cargo lowering due regimeparametric optimization and study the obtained results with dynamic and energy indicators.

Methodology. In order to carry out the regime-parametric optimization of the mine winder deceleration mode the direct Euler's variational and differential evolution methods have been used. In order to study the approximate solution of the variational problem the mathematical modeling and integration of differential equations methods were used.

Findings. It was established that in comparison with rational laws of the mine winder deceleration using the optimum torque law reduces unwanted dynamic loads in the rope up to $28.4 \%$, and in the coupling by $15.4 \ldots 82.7 \%$. In this case, the oscillations of the drive and the final cargo at the end of deceleration do not exist. In aggregate, it allows increasing the reliability of the mine winder. The optimal value of the reduced coefficient of coupling stiffness of the mine winder actuator has been established.

Originality. The formulation of an optimization problem has been carried out. The complex terminal-integral criterion has been chosen. It was shown that in the formulation of the problem it is necessary to introduce the extra boundary conditions for achieving the absolute minimums of the terminal criteria. In order to find an approximate solution to the mine winder deceleration mode optimization problem, sampling of the problem was carried out. The solution of the problem was found on a set, which is the conjunction of two domains: the dynamic parameters of the mine winder and its modes of motion.

Practical value. The calculated optimal deceleration mode of the machine may be implemented with the frequencycontrolled drive, which allows increasing the efficiency of the mine winder operation in terms of dynamic indicators.

Keywords: mine lift, regime-parametric optimization, dynamic loads, energy indicators

Introduction. The state-of-art mine winders work in quite hard regimes. Basically, it is connected with demands of their high productivity and load capacity. At another point, a mine winder should be reliable; its operation life must be as long as possible. Mentioned above demands are contradictory. In order to meet them (to a greater or a lesser extent) designers of a mine winder should find compromises.

One of the ways to find such compromises is to design a mine winder with optimal parameters. Moreover, designers of the mine winder control system should develop the speed diagrams for different regimes of mine winder motion. The solutions of both problems in aggregate allow improving the processes effectiveness of the hoist machine.

Analysis of the recent research. Dynamic effects in elements of mine winders have been studied in many works. In articles $[1,2]$ the analytical expressions of maximum loads in rope in different operation conditions were obtained. In many articles numerical simulation was used $[3,4]$. It has been stated that rope tension is the function of a machine movement regime [4] and machine parameters [5] (some of them may be non-linear [6]).

Researchers in the mentioned works used mathematical models which are based on ordinary [3] and partial [1] differential equations.

In the article [2] correlation between rope tensions and fretting and fatigue parameters were established. The results of the investigation [7] show the danger of collision between two adjacent ropes. It is caused by large axial fluctuating displacements of head sheaves.

(C) Loveikin V.S., Romasevych Yu. O., 2018
Dangerous dynamic loads in the mine hoisting rope are also connected with its internal spiral components [5]. In the work [8] the connection between the dynamic loads and safety of exploitation of shafts is researched.

In the analyzed works only peak (maximum and minimum) values of the rope tension were taken into consideration. The indicators which reflect the common load (for instance, the root-mean-square value) during the transient regime have not used. Moreover, the loads in other elements of a mine winder are still unstudied.

There are many scientific works in which a mine winder control issues have been studied. For these purposes use classical [9] and non-classical [10, 11] methods of automatic control theory. They allow controlling the mine winder final (terminal) cargo movement. It is notable that in the work [11] the problem statement of the mine winder optimal control is shown, but its solution has not been given. In the article [12] the speed curve of the mine hoist has been obtained. It is smooth and piecewise. Obviously, that character of the speed curve is attended with low level of dynamic loads which is desirable.

In conclusion, it is necessary to mention the works $[13,14]$ in which the implementation of a mine winder control has been studied. The state-of-the-art approach in this field is using the programmable industrial controllers with specific communication channels and reliably protected sensors.

Unresolved issues. Nowadays, a mine winder, as well as other lifting machinery [15], is a complex mechatronic system. The movement control of a mine winder is connected with using industrial controllers. These devices can be programmed by some means or others. The 
software of a mine winder control system should include the optimal (in some sense) laws of its motion. The implementation of the optimal laws can be performed with the high-capacity frequency inverters.

Thus, the main problem at the stage of the previous calculation of the mine winder motion regimes is selection of the "right" optimization criterion and the effective method for problem solving.

Unsolved aspects of the problem. The general approach to improvement of a mine winder processing should take into account the processes of different nature (dynamic, energy, electrical and information). That broad problem statement allows obtaining the increasing of mine winder efficiency by means of rational changing of its construction and/or control system software. However, the conducted analysis showed that deep studies of mine winders considered the effects which are caused only a few factors. It is desirable to study the mine winder movement from regime and parametric perspective.

Moreover, the results which will be obtained should be compared with the results of known scientific works and a best practice.

Objectives of the article. The objectives are improving the mine winder operation efficiency during deceleration of the final cargo lowering due regime-parametric optimization and study the obtained results with dynamic and energy indicators.

Presentation the main research. In order to carry out the study we have chosen a mine winder dynamic model, which is described in the previous study (Fig. 1 in the work [16]).

The mathematical model which meets the mine winder dynamic model can be presented as follows

$$
\left\{\begin{array}{l}
M=J_{1} \ddot{\varphi}_{1}+c_{\varphi}\left(\varphi_{1}-\varphi_{2}\right) \\
c_{\varphi}\left(\varphi_{1}-\varphi_{2}\right)=J_{2} \ddot{\varphi}_{2}+c_{x}\left(\varphi_{2} R-x\right) R, \\
c_{x}\left(\varphi_{2} R-x\right)=m \ddot{x}+F
\end{array}\right.
$$

where $J_{1}$ is the reduced moment of inertia of the motor rotor and the first half-coupling; $J_{2}$ is the reduced moment of inertia of the second half-coupling, the gearbox and rope drum; $m$ is reduced to the vertical motion weight of final cargo; $R$ is rope drum radius; $c_{\varphi}$ is reduced coefficient of coupling stiffness; $c_{x}$ is reduced coefficient of rope stiffness; $M$ is reduced torque of mine winder drive; $F$ is reduced resistance force during skip motion. All mine winder dynamic parameters are reduced to rope drum. The point above the symbol means differentiation by time.

The important part of the research is the choice of optimization criterion. We have chosen the complex integral-terminal - criteria $C_{r}$, which can be presented in the following form

$$
\left\{\begin{array}{l}
C r=\operatorname{Ter}_{0}+\operatorname{Ter}_{T}+I n t \rightarrow \min \\
\operatorname{Ter}_{0}=\delta_{\dot{M}} \dot{M}^{2}(0) \\
\operatorname{Ter}_{T}=\delta_{\dot{M}} \dot{M}^{2}(T) \\
\operatorname{Int}=T^{-1} \int_{0}^{T}\left(\begin{array}{l}
\delta_{1} M^{2}+\delta_{2}\left(c_{x}\left(\varphi_{2} R-x\right)\right)^{2}+ \\
+\delta_{3}\left(c_{\varphi}\left(\varphi_{1}-\varphi_{2}\right)\right)^{2}+\delta_{4} \dot{M}^{2}
\end{array}\right) d t
\end{array},\right.
$$

where $T$ is duration of the system deceleration to the quiescent state; $\delta_{1}, \delta_{2}, \delta_{3}$ and $\delta_{4}$ are ratios, which drive the respective components to dimensionless form and determine the importance of each of the components in the criterion structure; $\delta_{\dot{M}}$ is the ratio, which drive the terminal criteria $\operatorname{Ter}_{0}$ and $\mathrm{Ter}_{T}$ to the dimensionless form.

Minimization of terminal criteria $\operatorname{Ter}_{0}$ and $\mathrm{Ter}_{T}$ allows avoiding the "soft" interference between the mine winder transmission elements.

Minimization of the expression at $\delta_{1}$ causes increasing energy efficiency of the mine winder drive and dynamic loads in the machine will decrease as well. The components at $\delta_{2}$ and $\delta_{3}$ reflect the force in the rope and torque in the coupling, respectively.

The expression at $\delta_{4}$ shows the rate of the drive torque changing. It minimization is required under conditions of normal operation of the mine winder drive.

All the ratios can be presented as follows

$$
\left\{\begin{array}{l}
\delta_{1}=k_{1}\left(v R^{-1} P^{-1}\right)^{2} \\
\delta_{2}=k_{2}(m g)^{-2} \\
\delta_{3}=k_{3}\left(v R^{-1} P^{-1}\right)^{2} \\
\delta_{4}=\left(1-k_{1}-k_{2}-k_{3}\right) T^{4} \times \\
\times\left(2\left(F R T-2 R\left(m r^{2}+J_{1}+J_{2}\right)\right)\right)^{-2} \\
\delta_{\dot{M}}=T^{4}\left(2\left(F R T-2 R\left(m r^{2}+J_{1}+J_{2}\right)\right)\right)^{-2}
\end{array}\right.
$$

where $k_{1}, k_{2}, k_{3}$ are weight coefficients which show the significance of the respective components at the criterion Int structure; $P$ is the rated power of the mine drive; $v$ is the constant final cargo motion speed.

Criteria (2) can be presented in another form

$$
\left\{\begin{array}{l}
\operatorname{Ter}_{0}=\delta_{\dot{M}}\left(\sum_{i=1}^{3} A_{i} x^{(2 i+1)}(0)\right)^{2} \\
\operatorname{Ter}_{T}=\delta_{\dot{M}}\left(\sum_{i=1}^{3} A_{i} x^{(2 i+1)}(T)\right)^{2} \\
\operatorname{Int}=T^{-1} \int_{0}^{T}\left(\delta_{1}\left(A_{0}+\sum_{i=1}^{3} A_{i} x^{(2 i)}\right)^{2}+\delta_{2}(F+m \ddot{x})^{2}+\right. \\
\left.+\delta_{3}\left(B_{0}+\sum_{j=1}^{2} B_{j} x^{(2 i)}\right)^{2}+\delta_{4}\left(\sum_{i=1}^{3} A_{i} x^{(2 i+1)}\right)^{2}\right) d t
\end{array}\right.
$$

where $A_{0} \ldots A_{3}$ and $B_{0} \ldots B_{2}$ are constants which are determined as follows

$$
\left\{\begin{array}{l}
A_{0}=F R \\
A_{1}=\left(J_{1}+J_{2}\right) R^{-1}+m R \\
A_{2}=\left(m R J_{1} c_{\varphi}^{-1}+J_{1} J_{2}\left(c_{\varphi} R\right)^{-1}\right)+m\left(J_{1}+J_{2}\right)\left(c_{x} R\right)^{-1} \\
A_{3}=J_{1} J_{2} m\left(c_{x} c_{\varphi} R\right)^{-1} \\
B_{0}=F J_{2} \\
B_{1}=m+J_{2} R^{-1} \\
B_{2}=m J_{2}\left(c_{x} R\right)^{-1}
\end{array} .\right.
$$


The boundary conditions of the system are as follows

$$
\left\{\begin{array}{l}
\varphi_{1}(0)=0 ; \quad \varphi_{2}(0)=-F R c_{\varphi}^{-1} ; \quad x(0)=-F R^{2} c_{\varphi}^{-1}-F c_{x}^{-1} \\
\dot{x}(0)=-v ; \quad \dot{\varphi}_{1}(0)=\dot{\varphi}_{2}(0)=-v R^{-1} \\
x(T)=-F R^{2} c_{\varphi}^{-1}-F c_{x}^{-1}-s ; \quad \varphi_{2}(T)=-F R^{2} c_{\varphi}^{-1}-s R^{-1}, \\
\varphi_{1}(T)=-s R^{-1} ; \quad \dot{x}(T)=\dot{\varphi}_{1}(T)=\dot{\varphi}_{2}(T)=0
\end{array},\right.
$$

where $s$ is the distance which the cargo has passed during deceleration regime. The boundary conditions (6) can be expressed through higher derivatives of $\mathrm{x}(t)$ by time, whereby we have obtained

$$
\left\{\begin{array}{c}
x(0)=F R^{2} c_{\varphi}^{-1}+F c_{x}^{-1} ; \quad \dot{x}(0)=-v ; \\
\ddot{x}(0)=\dddot{x}(0)=x(0)=x(0)=0 \\
x(T)=F R^{2} c_{\varphi}^{-1}+F c_{x}^{-1}+s ; \\
\dot{x}(T)=\ddot{x}(T)=\dddot{x}(T)=x(T)=x(T)=0
\end{array} .\right.
$$

The analysis of the expressions (4) and (7) shows that taking into account the extra boundary conditions

$$
\left\{\begin{array}{l}
V I \quad V I I \\
x(0)=x(0)=0 \\
V I \quad V I I \\
x(T)=x(T)=0
\end{array},\right.
$$

allows meeting the absolute minimums of the terminal criteria $\mathrm{Ter}_{0}$ and $\mathrm{Ter}_{T}$.

In work [16] it is found that the integral criterion of the seventh order (the highest derivative of the function $x(t)$ in the integrand) cannot be used in order to find the exact solution of the optimization problem. It is connected with the fact that characteristic equation of the Euler-Poisson's equation is of the fifth order. It is impossible to find the solution of that kind of the equation [17].

We can only find the approximate solution of the problem (1-7). We will use the Euler's direct variation method [18]. In order to find the approximate solution we have to use discrete values of the functions.

Moreover, the approximate solution must be found in a conjunction of the regime and parametric domains. It allows obtaining the less value of the criterion (2) compared with the value obtained only in the regime domain. In the article we use the simplest approximation of the derivative

$$
\begin{gathered}
n+1 \\
x\left(t_{i}+2^{-1}\left(t_{i}-t_{i-1}\right)\right)=\lim _{t_{i}-t_{i-1} \rightarrow 0} \frac{x_{i}-x_{i-1}}{t_{i}-t_{i-1}} \approx \frac{x_{i}-x_{i-1}}{t_{i}-t_{i-1}},
\end{gathered}
$$

if the remainder $t_{i}-t_{i-1}$ is rather small.

In expression (9) $n$ means the order of derivative by time and $i$ is the index which corresponds to the discrete moment of the time $t_{i}$. So, we will consider the discrete function $x_{i}\left(t_{i}\right)$ (in the subsequent the notation $x_{i}$ will be used). Discrete function $x_{i}$ must meet the conditions which can be obtained from boundary conditions (7) and (8). These conditions are as follows

$$
\left\{\begin{array}{l}
x_{0}=F R^{2} c_{\varphi}^{-1}+F c_{x}^{-1} ; \quad\left(x_{1}-x_{0}\right) \Delta t^{-1}=-v \\
\left(x_{2}-2 x_{1}+x_{0}\right) \Delta t^{-2}=0 \\
\left(x_{3}+3 x_{2}-3 x_{1}-x_{0}\right) \Delta t^{-3}=0 \\
\left(x_{4}-4 x_{3}+6 x_{2}-4 x_{1}+x_{0}\right) \Delta t^{-4}=0 \\
\left(x_{5}-5 x_{4}+10 x_{3}-10 x_{2}+5 x_{1}-x_{0}\right) \Delta t^{-5}=0 \\
\left(x_{6}-6 x_{5}+15 x_{4}-20 x_{3}+15 x_{2}-6 x_{1}+x_{0}\right) \Delta t^{-6}=0 \\
\left(x_{7}-7 x_{6}+21 x_{5}-35 x_{4}+35 x_{3}-21 x_{2}+7 x_{1}-\right. \\
\left.-x_{0}\right) \Delta t^{-7}=0 \\
x_{N-1}=F R^{2} c_{\varphi}^{-1}+F c_{x}^{-1}+s ; \quad\left(x_{N-2}-x_{N-1}\right) \Delta t^{-1}=0 \\
\left(x_{N-3}-2 x_{N-2}+x_{N-1}\right) \Delta t^{-2}=0 \\
\left(x_{N-4}+3 x_{N-3}-3 x_{N-2}-x_{N-1}\right) \Delta t^{-3}=0 \\
\left(x_{N-5}-4 x_{N-4}+6 x_{N-3}-4 x_{N-2}+x_{N-1}\right) \Delta t^{-4}=0 \\
\left(x_{N-6}-5 x_{N-5}+10 x_{N-4}-10 x_{N-3}+5 x_{N-2}-\right. \\
\left.-x_{N-1}\right) \Delta t^{-5}=0 \\
\left(x_{N-7}-6 x_{N-6}+15 x_{N-5}-20 x_{N-4}+15 x_{N-3}-\right. \\
\left.-6 x_{N-2}+x_{N-1}\right) \Delta t^{-6}=0 \\
\left(x_{N-8}-7 x_{N-7}+21 x_{N-6}-35 x_{N-5}+35 x_{N-4}-\right. \\
\left.-21 x_{N-3}+7 x_{N-2}-x_{N-1}\right) \Delta t^{-7}=0
\end{array},\right.
$$

where $N$ is the number of the discretization steps; $\Delta t$ is the time step i.e. the distance between nearest-neighbor moments of time at the discrete time axis (values $N, \Delta t$ and $T$ are connected with following expression $\Delta t=$ $=T N^{-1}$ ). The system of algebraic equations (10) allows to find the fourteen values $x_{0}, \ldots, x_{7}, x_{N-8}, \ldots, x_{N-1}$.

Using the discrete values of the function $x(t)$ allows formulating the following optimization problem - it is necessary to find the $N-14+2$ unknown values, which minimize the Riemann sum

$$
\begin{gathered}
\text { Int } \approx \operatorname{Sum}_{\text {Int }}=\sum_{k=7}^{N-8}\left(\delta _ { 1 } \left(A_{0}+A_{1} \Delta t^{-2}\left(x_{k+2}-2 x_{k+1}+\right.\right.\right. \\
\left.+x_{k}\right)+A_{2} \Delta t^{-4}\left(x_{k+4}-4 x_{k+3}+6 x_{k+2}-4 x_{k+1}+x_{k}\right)+ \\
+A_{3} \Delta t^{-6}\left(x_{k+6}-6 x_{k+5}+15 x_{k+4}-20 x_{k+3}+15 x_{k+2}-\right. \\
\left.\left.-6 x_{k+1}+x_{k}\right)\right)^{2}+\delta_{2}\left(F+m \Delta t^{-2}\left(x_{k+2}-2 x_{k+1}+x_{k}\right)\right)^{2}+ \\
+\left(\delta _ { 3 } \left(B_{0}+B_{1} \Delta t^{-2} \times\left(x_{k+2}-2 x_{k+1}+x_{k}\right)+\right.\right. \\
\left.+B_{2} \Delta t^{-2}\left(x_{k+4}-4 x_{k+3}+6 x_{k+2}-4 x_{k+1}+x_{k}\right)\right)^{2}+ \\
+\delta_{4}\left(\grave{A}_{1} \Delta t^{-3}\left(x_{k+3}+3 x_{k+2}-3 x_{k+1}-x_{k}\right)+\grave{A}_{2} \times\right. \\
\times \Delta t^{-5}\left(x_{k+5}-5 x_{k+4}+10 x_{k+3}-10 x_{k+2}+5 x_{k+1}-x_{k}\right)+ \\
+\dot{A}_{3} \Delta t^{-7}\left(x_{k+7}-7 x_{k+6}+21 x_{k+5}-35 x_{k+4}+35 x_{k+3}-\right. \\
\left.\left.-21 x_{k+2}+7 x_{k+1}-x_{k}\right)\right)^{2} .
\end{gathered}
$$

The two extra values which minimize the $S u m_{\text {Int }}$ are $S$ and $c_{\varphi}$

For numerical calculation the parameters of mine winder were used: $m=4400 \mathrm{~kg} ; J_{1}=2400 \mathrm{~kg} \cdot \mathrm{m}^{2} ; J_{2}=$ $=2000 \mathrm{~kg} \cdot \mathrm{m}^{2} ; R=2 \mathrm{~m} ; c_{x}=1.06 \cdot 10^{5} \mathrm{~N} / \mathrm{m}$. The regime parameters assumed are the following: $T=4 \mathrm{~s} ; v=$ $=12 \mathrm{~m} / \mathrm{s} ; k_{1}=k_{2}=0.4 ; k_{3}=0.15$. These weight coeffi- 
cients are assumed on a compromise basis. The significance of the corresponding components in the criterion (4) was taken into consideration as well.

The stated problem has been solved with differential evolution method [19]. As a result, the values $x_{8}, \ldots$, $x_{N-8}, s$ and $c_{\varphi}$ were found. The optimal values of $s$ and $c_{\varphi}$ are: $s=v T 2^{-1}$ and $c_{\varphi}=1.55 \cdot 10^{9} \mathrm{Nm} / \mathrm{rad}$.

The basic construction of the mine winder has the coupling with reduced coefficient of stiffness which is equal to $1.2 \cdot 10^{9} \mathrm{Nm} / \mathrm{rad}$. So, within the framework of the study that value of the coefficient $c_{\varphi}$ is not optimal.

The drive of the considered mine winder includes the high voltage asynchronous motor with phase rotor АКН-2-16-39-12УХЛ4 (rated-power output is $500 \mathrm{~kW})$. The mine winder drive can work in braking mode (regenerative braking). It is possible due to stateof-the-art inverters (they act as a mine winder drive power source) [20].

In order to illustrate the main characteristics of the optimal law of the mine winder, the motion diagrams are shown (Fig. 1). As the optimal law is discrete function $x i$ we have found the discrete function of: angular velocity, drive power, rope force, and coupling torque.
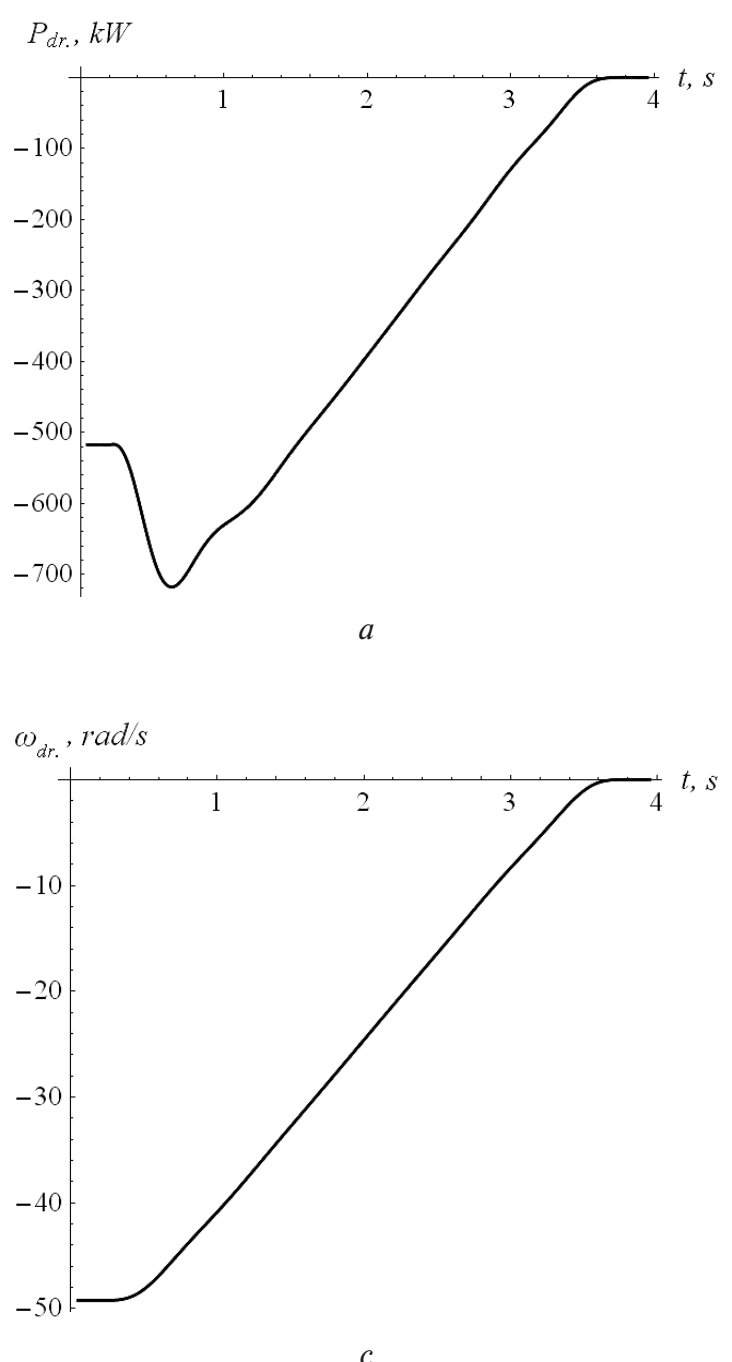

Then we built the third order spline functions of the mentioned characteristics (Fig. 1).

We should notice that all diagrams are smooth. Moreover, the increase and decrease in the functions about initial and final moments of time are very slow. It is a result of the minimization of the terminal criteria $\mathrm{Ter}_{0}$ and $\mathrm{Ter}_{T}$. The advantages of that approach to the problem solving will be shown further.

The residual oscillation of the coupling and the cargo (skip) do not exist. That means that dynamic forces in rope and coupling after deceleration would be minimized and (as consequence) the operation life of the mine winder would increase.

As has been noted above, the modern inverters can implement the diagram of the deceleration torque. They can implement other shapes of deceleration torque as well. In order to carry out the comparative analysis the different shapes of deceleration torque were selected. They are: constant, triangle-shaped, trapezium-shaped, U-shaped and S-shaped ones.

The calculations were carried out for two cases:

1) the deceleration torque is constant $(130 \mathrm{kNm})$ and the deceleration duration is variable;

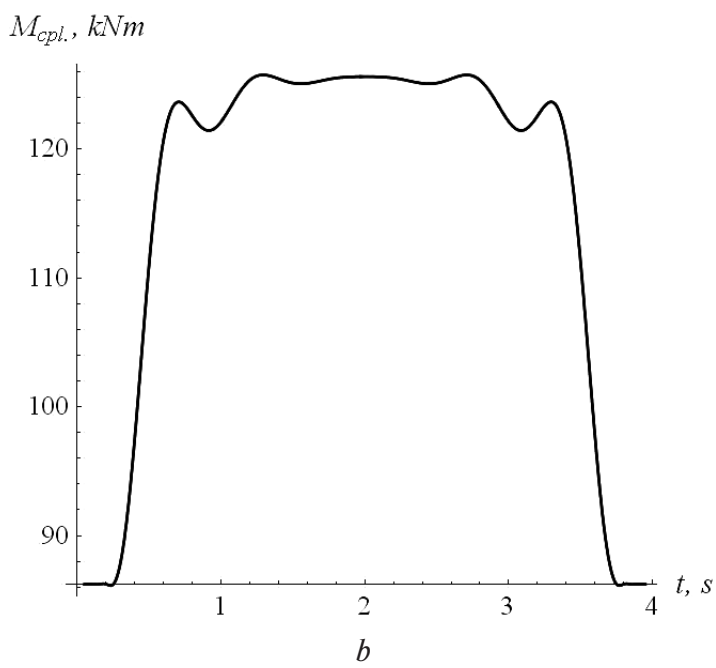

$F_{\text {rop. }}, k N$

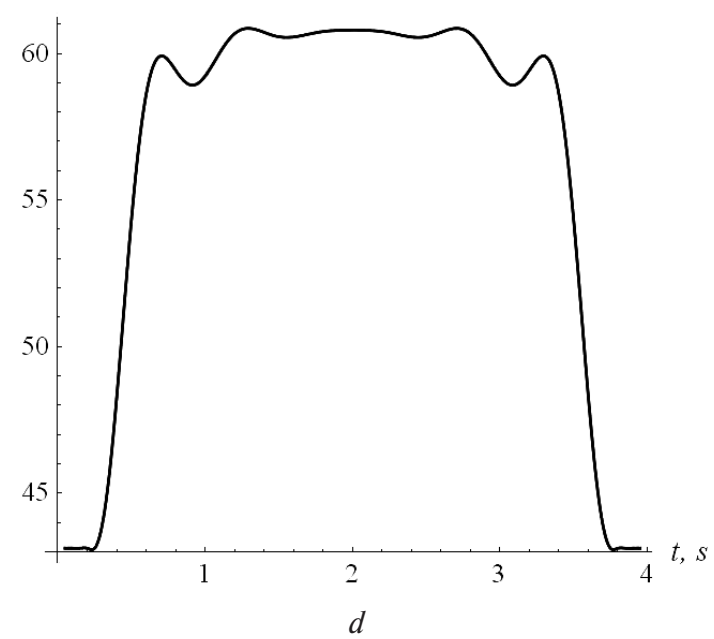

Fig. 1. Diagrams of mine winder motion characteristics during its deceleration:

$a-$ drive power; $b$-torque in the flexible coupling; $c$-drive angular velocity; $d$-force in the rope 
2) the deceleration torque is variable and the deceleration duration $(4 \mathrm{~s})$ is constant. These constant values selected as the parameters of the found optimal law.

The variable values for each deceleration torque law and for each case were calculated on the basis of the mine winder stopping.

The diagrams of the deceleration torque for the both cases have been shown in Fig. 2.

In Fig. 2 assumed that increasing and decreasing duration is equal to $1.1 \mathrm{~s}$. These durations for optimal law of deceleration torque is about the same.

The results of carried out calculations are in the Table. The biggest values are marked in gray and the smallest ones - in bold. Comparing analysis of the coupling torque allowed stating that using the optimal control is the best way to reduce the load in this element of the mine winder transmission. The reducing of unwanted dynamic loads is within $15.4 \ldots 82.7 \%$.

The maximum of the load in the rope is not big. It equals the same value which corresponds to triangleshaped deceleration torque. But for the last case, the duration of the deceleration is almost by one and a half times bigger. The reducing of unwanted dynamic loads in the rope for all considerate deceleration torque laws is up to $28.4 \%$. So, the optimal law shows advantages in terms of reducing the dynamic loads in elements of the mine winder. The energy indicators show that optimal law of the deceleration torque does not cause the decrease in the unwanted energy losses. We did not use the energy component in the criterion (4) in the study. So, the energy indicators did not improve compared with laws of the deceleration torque taken in the calculations.
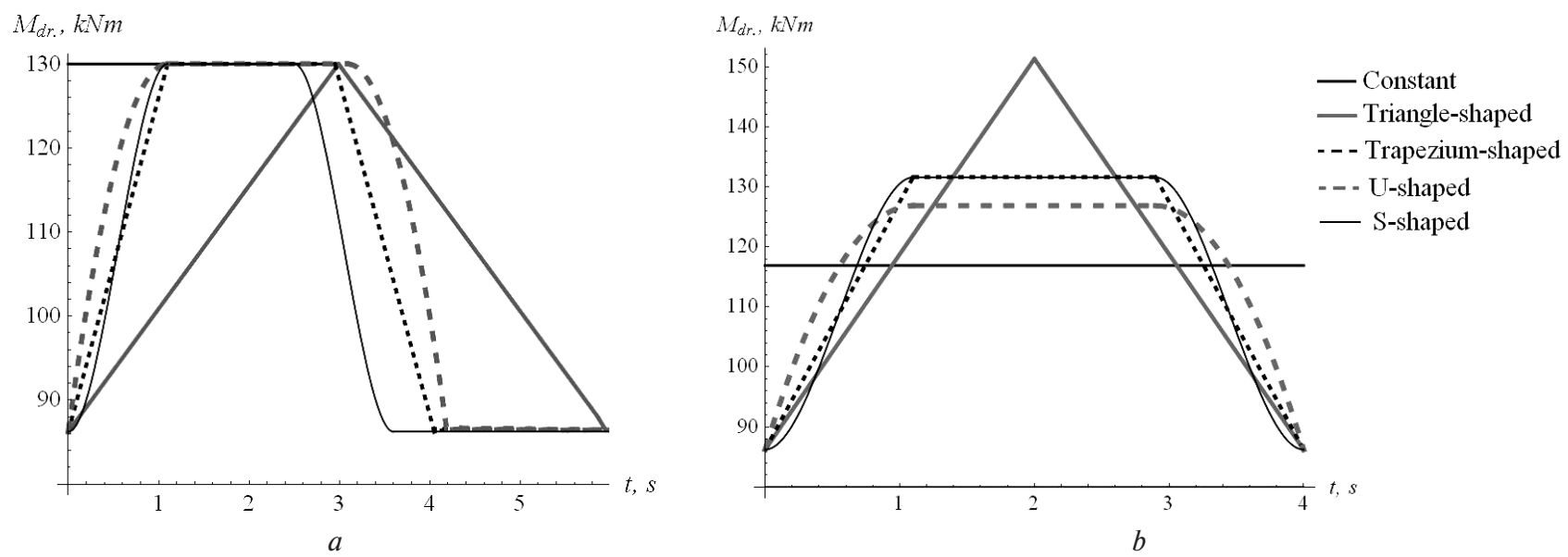

Fig. 2. Diagrams of drive deceleration torque shapes selected for comparative analysis:

$a$-for the first case; $b$ - for the second case

Table

The dynamic and energy indicators which correspond to different laws of the deceleration torque

\begin{tabular}{|c|c|c|c|c|c|c|c|c|c|}
\hline $\begin{array}{l}\text { Deceleration } \\
\text { torque law }\end{array}$ & 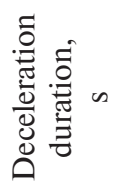 & 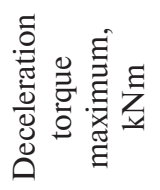 & 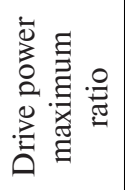 & 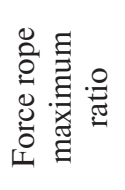 & 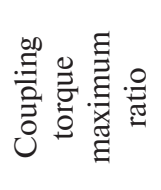 & 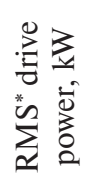 & 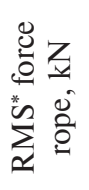 & 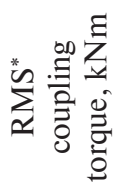 & 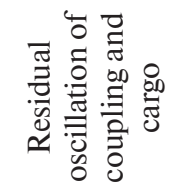 \\
\hline Optimal & 4.00 & 130.0 & 1.43 & 1.41 & 1.46 & 427.0 & 57.0 & 116.0 & does not exist \\
\hline \multicolumn{10}{|c|}{ The first case } \\
\hline Constant & 2.89 & \multirow[t]{5}{*}{130.0} & 1.56 & 1.81 & 2.44 & 459.9 & 61.7 & 133.9 & \multirow[t]{5}{*}{ exists } \\
\hline Triangle-shaped & 5.86 & & 1.15 & 1.41 & 2.41 & 397.8 & 52.3 & 122.0 & \\
\hline Trapezium-shaped & 4.05 & & 1.28 & 1.42 & 2.45 & 426.1 & 56.7 & 130.8 & \\
\hline U-shaped & 4.19 & & 1.33 & 1.44 & 2.46 & 419.4 & 56.0 & 129.7 & \\
\hline S-shaped & 3.60 & & 1.35 & 1.48 & 2.48 & 436.9 & 58.1 & 133.7 & \\
\hline \multicolumn{10}{|c|}{ The second case } \\
\hline Constant & \multirow[t]{5}{*}{4.00} & 116.9 & 1.41 & 1.57 & 2.31 & 416.7 & 55.9 & 124.3 & \multirow[t]{5}{*}{ exists } \\
\hline Triangle-shaped & & 151.3 & 1.25 & 1.65 & 2.66 & 421.8 & 56.2 & 129.9 & \\
\hline Trapezium-shaped & & 131.6 & 1.29 & 1.44 & 2.47 & 427.4 & 56.7 & 131.0 & \\
\hline U-shaped & & 126.8 & 1.33 & 1.44 & 2.44 & 413.9 & 56.3 & 131.1 & \\
\hline S-shaped & & 131.5 & 1.36 & 1.46 & 2.47 & 422.1 & 56.4 & 130.4 & \\
\hline
\end{tabular}

${ }^{*}$ RMS is a root mean-square value 
Summing everything up, we state that the main factors for the mine winder dynamics are the regime duration and the nature of increasing and decreasing the deceleration torque.

Conclusions and recommendations for further research. In the article it is shown that the problem of increasing dynamic performance of the mine winder is complex. So, its solution should be found in the complex domain. Such domain within the framework of the study involved the conjunction of regime and parameter domains of the mine winder.

The implementation of the mine winder optimal control allows increasing dynamic performance of the machine. In turn, it makes operation life of the machine longer. The optimal value of the reduced coefficient of the coupling stiffness destinduished in the study will be useful during the mine winder design process. Complex approach to optimization of the mine winder deceleration has shown its efficiency.

In the comparative analysis we used different deceleration torque laws. In general, the optimal deceleration law of the mine winder is the best. However, some deceleration torque laws have better indicators than the optimal one. This suggests that reserves for improving the mine winder operation exist.

Prospects for further studies consist, as mentioned above, in using the criteria with influence component which reflects the energy processing of the mine winder (for instance, energy losses of electric drive). It causes the necessity of using non-linear criteria. In order to find the solution of such nonlinear optimal control problem the methods used in the article can be apply. Of course, the energy optimal solution should meet defined constrains and parameters of the mine winder. Thus, the solution will be not universal.

\section{References.}

1. Wolny, S., 2017. Emergency braking of a mine hoist in the context of the braking system selection. Archives of Mining Sciences, 62(1), pp. 45-54. DOI: 10.1515/amsc2017-0004.

2. Dagang, W., Dekun, Z. and Shirong, G., 2014. Effect of terminal mass on fretting and fatigue parameters of a hoisting rope during a lifting cycle in coal mine. Engineering Failure Analysis, 36, pp. 407-422. DOI: 10.1016/j.engfailanal.2013.11.006.

3. Chenming, W., Jisheng, W., Bo, D., Iitao, F. and Shengli, Z., 2016. The Influence to Mine Hoisting Steel Wire Rope Tension and Deformation from Velocity and Acceleration. International Conference on Manufacturing Science and Information Engineering, pp. 296-306. DOI: $10.12783 /$ dtcse/icmsie2016/6345.

4. Dagang, W., Dekun, Z., Xianbiao, M., Yuxing, P. and Shirong, G., 2015. Dynamic friction transmission and creep characteristics between hoisting rope and friction lining. Engineering Failure Analysis, 57, pp. 499-510. DOI: 10.1016/j.engfailanal.2015.08.010.

5. Jun, Z., Dagang, W., Dekun, Z., Shirong, G. and Dao'ai, W., 2017. Dynamic torsional characteristics of mine hoisting rope and its internal spiral components.
Tribology International, 109, pp. 182-191. DOI: 10.1016/j.triboint.2016.12.037.

6. Chao, J., Yanshu, L., Bohua, W., Shuangshuang, Z. and Xue, L., 2013. Research on nonlinear dynamical behaviors of mine hoist transmission system under external excitation. Advanced Materials Research, 619, pp. 9-13. DOI: 10.4028/www.scientific.net/AMR.619.9.

7. Yao, J., Xiao, X., Peng, A., Jiang, Y. and Ma, C., 2015. Assessment of safety for axial fluctuations of head sheaves in mine hoist based on coupled dynamic model. Engineering Failure Analysis, 51, pp. 98-107. DOI: 10.1016/j.engfailanal.2015.02.011.

8. Illin, S. R., Samusia, V. I., Ilina I.S. and Ilina, S. S., 2016. Influence of dynamic processes in mine hoists on safety of exploitation of shafts with broken geometry. Naukovyi Visnyk Natsionalnoho Hirnychoho Universytetu, 3, pp. 48-53.

9. Dai, Y. and Qiao, S., 2014. The Design of Mine Hoist Speed Regulation System Based on Ziegler-Nichols PID Control. Applied Mechanics and Materials, 651653, pp. 996-999.

10. Wu, Y.X., Zhang, C. J. and Liu, Y. Q., 2013. Design and Simulation of Fuzzy-PID Vector Control System Based on Mine Hoist. Applied Mechanics and Materials, 300-301, pp. 1486-1489. DOI: 10.4028/www.scientific. net/AMM.300-301.1486.

11. Szymański, Z., 2015. Intelligent, energy saving power supply and control system of hoisting mine machine with compact and hybrid drive system. Archives of Mining Sciences, 60(1), pp. 239-251. DOI: 10.1515/amsc-2015-0016. 12. Yang, Z. S. and Ma, X. M., 2014. Synthesis of Mine Hoist Speed Curve Based on programmable logic controller. Advanced Materials Research, 846-847, pp. 9093. DOI: 10.4028/www.scientific.net/AMR.846-847.90. 13. Zewen, W., Wei, L., Baoyu, C. and Fan, J., 2012. Design of the Remote Monitoring System for Mine Hoists. In: 24th Chinese Control and Decision Conference, pp. 3540-3544. DOI: 10.1109/CCDC.2012.6244567.

14. Huaizhong, C., 2012. Study on PROFIBUS-DP Field Bus in Mine Hoists Control System. Advanced Materials Research, 482-484, pp. 1781-1784. DOI: 10.4028/www.scientific.net/AMR.482-484.1781.

15. Loveikin, V. S., Chovniuk, Yu. V. and Liashko, A. P., 2014. The crane's vibrating systems controlled by mechatronic devices with magnetorheological fluid: the nonlinear mathematical model of behavior and optimization of work regimes. Naukovyi Visnyk Natsionalnoho Hirnychoho Universytetu, 6, pp. 97-102.

16. Loveikin, V.S. and Romesevych, Yu. O., 2017. Dynamic optimization of a mine winder acceleration mode. Naukovyi Visnyk Natsionalnoho Hirnychoho Universytetu, 4, pp. 81-87.

17. Bronshtein, I. N. and Semendyayev, K.A., 2013. Handbook of mathematics. 3rd ed. Springer Science \& Business Media [online]. Available at: <https://www. springer.com/gp/book/9783662462201> [Accessed 25 September 2017].

18. Gander, M. J. and Wanner, G., 2012. From Euler, Ritz, and Galerkin to Modern Computing. SIAM REVIEW [online], 54, 4. Available at: <http://www.siam.org/journals/sirev/54-4/80403.html > [Accessed 11 August 2017]. 
19. Storn, R., 2014. Differential Evolution (DE) for Continuous Function Optimization (an algorithm by Kenneth Price and Rainer Storn) [online]. Available at: <http://www1.icsi.berkeley.edu/ storn/code.html> [Accessed 5 September 2017].

20. Prasad, H., Maity, T. and Babu, V. R., 2015 Recent developments in mine hoists drives. Journal of Mining Science, 51(6), pp. 1157-1164.

\section{Режимно-параметрична оптимізація гальмування шахтної підйомної машини}

\section{В. С. Ловейкін, Ю. О. Ромасевич}

Національний університет біоресурсів і природокористування України, м. Київ, Україна, e-mail: lovvs@ukr.net; romasevichyuriy@ukr.net

Мета. Покращення якості перехідного режиму гальмування шахтної підйомної установки під час опускання кінцевого вантажу за рахунок проведення режимно-параметричної оптимізації та дослідження отриманих результатів за енергетичними й динамічними показниками.

Методика. Для виконання режимно-параметричної оптимізації гальмування шахтної підйомної машини використано прямий варіаційний метод Ейлера та метод диференціальної еволюції. Для дослідження отриманого наближеного розв'язку варіаційної задачі застосовані методи математичного моделювання та інтегрування диференціальних рівнянь.

Результати. Встановлено, що у порівнянні з раціональними законами зміни гальмівного моменту шахтної підйомної машини використання знайденого в роботі оптимального гальмівного моменту дозволяє зменшити небажані динамічні навантаження в канаті до $28,4 \%$, а у пружній муфті на $15,4 \ldots 82,7 \%$. При цьому коливання елементів приводу та кінцевого вантажу в кінці гальмування відсутні. У сукупності це дозволяє підвищити надійність шахтної підйомної машини. Встановлене оптимальне значення приведеного коефіцієнта крутильної жорсткості з'єднувальної муфти приводу шахтної машини.

Наукова новизна. Виконана постановка оптимізаційної задачі, де в якості критерію обрано комплексний термінально-інтегральний критерій. Показано, що для досягнення абсолютних мінімумів термінальних критеріїв у постановку задачі необхідно ввести додаткові крайові умови. Для знаходження наближеного розв'язку задачі оптимізації режиму гальмування шахтної машини виконана іiі дискретизація. Розв'язок задачі знайдено на множині, що є кон'юнкцією областей динамічних параметрів шахтної машини й режимів ії руху.

Практична значимість. Розрахований оптимальний режим гальмування машини може бути реалізований за допомогою частотно-керованого приводу, що дає змогу підвищити ефективність роботи шахтної підйомної машини за динамічними показниками.

Ключові слова: шахтний підйом, режимно-параметрична оптимізація, динамічні навантаження, енергетичні показники

\section{Режимно-параметрическая оптимизация торможения шахтной подъемной машины}

\author{
В. С. Ловейкин, Ю. А. Ромасевич
}

Национальный университет биоресурсов и природопользования Украины, г. Киев, Украина, e-mail: lovvs@ ukr.net; romasevichyuriy@ukr.net

Цель. Улучшение качества переходного режима торможения шахтной подъемной установки при опускании концевого груза за счет проведения режимно-параметрической оптимизации и исследования полученных результатов по энергетическим и динамическим показателям.

Методика. Для проведения режимно-параметрической оптимизации торможения шахтной подъемной машины использован прямой вариационный метод Эйлера и метод дифференциальной эволюции. Для исследования полученного приближенного решения вариационной задачи применены методы математического моделирования и интегрирования дифференциальных уравнений.

Результаты. Установлено, что по сравнению с рациональными законами изменения тормозного момента шахтной подъемной машины использование найденного в работе оптимального тормозного момента позволяет уменьшить нежелательные динамические нагрузки в канате до $28,4 \%$, а в упругой муфте на $15,4 \ldots 82,7 \%$. При этом колебания элементов привода и концевого груза в конце торможения отсутствуют. В совокупности это позволяет повысить надежность шахтной подъемной машины. Установлено оптимальное значение приведенного коэффициента крутильной жесткости соединительной муфты привода шахтной машины.

Научная новизна. Выполнена постановка оптимизационной задачи, где в качестве критерия избран комплексный терминально-интегральный критерий. Показано, что для достижения абсолютных минимумов терминальных критериев в постановке задачи необходимо ввести дополнительные краевые условия. Для нахождения приближенного решения задачи оптимизации режима торможения шахтной машины выполнена ее дискретизация. Решение задачи найдено на множестве, которое является конъюнкцией областей динамических параметров шахтной машины и режимов ее движения.

Практическая значимость. Рассчитанный оптимальный режим торможения машины может быть реализован с помощью частотно-управляемого привода, что позволяет повысить эффективность работы шахтной подъемной машины по динамическим показателям.

Ключевые слова: шахтный подъем, режимно-параметрическая оптимизация, динамические нагруз$\kappa и$, энергетические показатели

Рекомендовано до публікації докт. техн. наук В.В.Гайдайчуком. Дата надходження рукопису 28.10.17. 